European journal of American studies

\title{
Dances with Westerns in Poland's Borderlands
}

\section{Piotr Skurowski}

\section{(2) OpenEdition \\ Journals}

Electronic version

URL: https://journals.openedition.org/ejas/13595

DOI: 10.4000/ejas.13595

ISSN: 1991-9336

Publisher

European Association for American Studies

\section{Electronic reference}

Piotr Skurowski, "Dances with Westerns in Poland's Borderlands ", European journal of American studies [Online], 13-3 | 2018, Online since 07 January 2019, connection on 08 July 2021. URL: http:// journals.openedition.org/ejas/13595 ; DOI: https://doi.org/10.4000/ejas.13595

This text was automatically generated on 8 July 2021 .

Creative Commons License 


\title{
Dances with Westerns in Poland's Borderlands
}

\author{
Piotr Skurowski
}

1 Parallel to other European countries, the American West has always stirred a great fascination in the Polish public. An important part of the Polish context which seems responsible for that fascination was the role played in Polish history by the eastern borderlands (Kresy) whose place in the Polish imaginary seems to parallel, in some important aspects, the mythmaking role played by the Wild West in America. The mythic appeal of the Kresy owes a lot to one of the key Polish mythmakers, the novelist Henryk Sienkiewicz whose famous Trilogy strongly defined the Polish imaginary concerning the history of the Kresy for generations to come. In Sienkiewicz's mythic vision, the Ukrainian steppes constituted a scenic backdrop for a heroic struggle of the righteous and chivalric Poles against the invasions of barbarian hordes from the East, including the Cossacks, Turks and Tartars. That vision of Polish history has long dominated the Polish historical imaginary in a way that paralleled the American mythic constructions of the Wild West, except that the Polish myth reversed the cardinal points from West to East and bestowed the civilizing mission on the Poles. ${ }^{1}$

Despite the dramatic reorientation in Poland's geopolitical situation after the Second World War (and the loss of the Kresy to the Soviet Union in the deal negotiated between Stalin and the Western powers) the myth of the "Wild East" continued to define the Polish identity (always constructed as "western"), even though it was now competing with the myth of the Recovered Territories, Poland's new borderland consisting of the previously German territories (Masuria, West Pomerania, Lower Silesia) where the autochtonic population was almost completely erased and replaced by the settlers shipped from the Kresy. ${ }^{2}$ The cardinal points of Polish history were once more rearranged, with the colonization moving westward and the settlers taking possession of the remaining German property dispensed by the new socialist authorities.

3 The myth of the Recovered Territories as Poland's own Wild West, where for a short time after the war the social and economic order practically ceased to exist and the 
vacated land and property were often grabbed on the first-come-first-served basis, was to some extent grounded in hard facts, though once the status of those territories was confirmed by the world powers the new Polish authorities were quickly proceeding with establishing a workable administration and the rule of law. The myth of the Recovered Territories, which found its expression in the government-sponsored propaganda and popular culture, ${ }^{3}$ consisted of some elements which were also notoriously present in the myth of the American West: the "emptiness" of the social space; the great opportunities awaiting the settlers; legitimacy of possession ("recovering" old Slavic lands as compared with Manifest Destiny); and the notion that the tough life in the new borderlands reinforces the "masculine" traits of heroism and physical prowess. Most importantly, the Recovered Territories became the place where a new socialist society was "officially" being forged and it comes as no surprise that the cultural apparatus of the People's Republic was making heavy use of the myth of new borderlands as the founding myth of the new Poland. In the following part of my article, I will look at a number of Polish film productions from the socialist period to show how this mythicizing effort domesticated and utilized the narrative devices and moral structure of the classic Western to help build a narration legitimizing the changes that occurred in Poland after the Second World War.

4 I will start with the work of Jerzy Skórzewski and Jerzy Hoffman, the latter-along with Andrzej Wajda-being undoubtedly one of the most important filmic narrators of Poland's national myths. Hoffman is an interesting case of a film director whose productions bear the imprint of Hollywood, without being imitations of American movies. His famous three-part adaptation of Sienkiewicz's Trilogy (With Fire and Sword, The Deluge, Wołodyjowski) featured the trappings of a Western (the omnipresent horse and horsemanship, the romance of the prairie-like steppe, the exotic bow-wielding Tartars and Cossacks, the chivalrous Polish protagonists), and his famous film version of Maria DĄbrowska's Noce i Dnie (Nights and Days) was dubbed by the critics "the Polish Gone with the Wind." However, it was his and Skórzewski's 1964 film Prawo i piĘść (The Law and the Fist, an adaptation of Józef Hen's novel) that featured a consistent and skillful use of the classic American Western's plot structure and aesthetics.

The film's action takes place in 1945 in the Recovered Territories (in Lower Silesia). The protagonist, Andrzej Kenig (Gustaw Holoubek)-an ex-prisoner of German concentration camps, lands a job with a group led by a Dr. Mielecki (Jerzy Przybylski) heading for a nearby town of Graustadt (Siwowo) to secure local property from theft. The town is deserted, its only inhabitants consisting of a group of four women and a German maitre d'hotel of the local Tivoli hotel. Upon arrival it turns out Mielecki is not a medical doctor but instead acts as the leader of a gang planning to steal the property left by the German inhabitants. The gangsters have no scruples killing anyone who gets in their way, including a militia man. ${ }^{4}$ Kenig decides to act alone, to prevent the bandits from disappearing with their loot loaded onto trucks. In a final shootout, Kenig kills off all the bandits except for one who manages to escape. In the end, when finally a militia jeep arrives at the scene, a militia lieutenant tries to persuade Kenig to remain in town, but the latter refuses and decides to move on.

6 Even though the film was set in Poland, the makers of the movie were honest about their American inspirations: in an interview, Hoffman and Skórzewski admitted that "we watched High Noon a lot of times, because it is-in our view-one of the best Westerns. And we wanted to do a Western" (Woroszylski). Consequently The Law and the 
Fist, while not literally a Western as it takes place in the war-devastated part of Central Europe in 1945 instead of the nineteenth-century American West, shares a lot with the classic American Western. It is a morality tale where the solitary hero conducts a lonesome fight against evil characters, with justice and order prevailing at the end. It is action-packed and contains a lot of violent scenes including fistfights and a final showdown between the hero and the villains, with the hero outmatching his opponents with his shooting skills. Like the Westerns, the film celebrates masculine toughness, even though the look and the acting style of the main Polish character, Kenig, played by Gustaw Holoubek, is rather that of a war-toughened intellectual than of a cowboy. The deserted Graustadt, or Siwowo, is presented as a lawless frontier town, a truly liminal space in transition caught in between its recent German past and the soon-toprevail new social and political order. In the meantime-in the absence of legitimate forces of law and order, community and social structure-like in classic Westerns, it takes the action of a single brave man to upkeep the principles of law and morality in the borderland even though the brutal logic of the recent war has devastated the long adhered to legal standards and notions of morality. This prominently includes the notions of private property: by a twist of irony, Kenig is defending the property deserted by its original owners-the Germans (even though, we might assume, some of it had already been plundered from the countries occupied by Germans) from being stolen as "szaber," 5 only to allow it to be taken over by the new Polish government to become public property, or be legally distributed to new owners.

7 There are a number of recognizable quotations from High Noon, including Kenig's looking for (and failing to find) allies for his approaching confrontation with the bandits and his solitary fight in the final scene; like in the American classic, we see two contrasting women characters, the "respectable" Anna (Zofia Mrozowska) and the sensuous Janka (Ewa Wiśniewska); there's the fistfight and a long hide-and-seek game between the hero and the villains in the dark interiors and narrow passages between buildings leading to the final shooting scene in the middle of a deserted town, with the lonely Kenig facing and dispatching the bandits. There is, too, the music by Krzysztof Komeda, with the famous "Nim wstanie dzień" ("Before a new day rises") song bringing immediately to mind Dimitri Tiomkin's opening ballad from High Noon. Most importantly, both films take up similar topics: the need to stand up to evil, even at the risk of one's life; and the tough beginnings leading to the emergence of a sense of community for a town sitting on the precarious border between lawlessness and civilization. And, of course, in the case of the Polish movie the emergence of the community is correlated with the emergence of the new socialist Poland.

8 For a movie that embraces the dawn of the new socialist order, Kenig seems not an entirely "appropriate" protagonist. Like many a film Western hero Kenig is an asocial, lonesome figure with a dark past-in fact, a past that couldn't possibly be darker: that of a prisoner of a concentration camp and an ex- Home Army soldier who fought in the doomed Warsaw Uprising. He is clearly not a proletarian figure, but rather a specimen of the Polish intelligentsia. We hardly know more about him, though, except thatalmost like Shane-he arrives out of nowhere and, at the end of the movie, decides to follow the road to an unknown destination. Kenig is not a materialist and-contrary to almost everybody else in the film-does not long for worldly goods and comforts of life (clearly a redeeming trait, given his "incorrect" background). But he decides to take on the bandits mainly not for ideological reasons, but because he was hired to protect the property and gave the man who hired him his word of honor. The moral code of the 
classic Western hero, putting honor above material gain, seems strikingly appropriate for a man who in effect becomes a socialist hero, keeping the acquisitive hyenas at bay and holding the town until the arrival of the militia.

The film's ending was obviously meant to send an ideological message: the arrival of the "legitimate" new rulers (militia) in a jeep at the end of the film is a reassuring sign that from now on lawlessness and anarchy are going to give room to a new social and political order-Polish and Communist. ${ }^{6}$ Yet Kenig has his own Will Kane moment, though he has no badge to throw into the dirt: he refuses the offer to serve as a communist official in the town he had saved from the plunderers. Leaving the incipient community to fend for itself, Kenig decides to head for an unknown destination-a restless and individualistic redeemer-hero, haunted by the dark past. We can almost hear him say the famous parting words of Shane to Joey: "there's no living with the killing." While not riding proudly off into the sunset-instead falling asleep on a jeep ride to the train station-Kenig protects his independence like an "authentic" Western hero. As the hero departs, we can see a long procession of settlers moving into the "saved" town to give it a new, socialist life. Parallel to the mythicization of conquest in classic Westerns-where the conquest was presented as the process of settling the "virgin land," Hoffman and Skorzewski's film passes over the brutal aspects of the eviction of the German population: instead, Siwowo/Graustadt is shown as an "empty" social space in need of being taken over, possessed, and reinvented by the new social order.

Other films located in the Recovered Territories in the immediately postwar period also featured components commonly perceived as Western-like, including displays of masculine brutality and toughness, but also the basic moral polarities of the Western at work in a borderland situation marked by the opposition between nature and civilization. Except that in the case of the Polish films, the "nature" or "wilderness" part of that opposition-or what is un-civilized-was also the desolation, physical and moral, left by the war. A good case in point was Waldemar Podgórski's Poludnik zero (Meridian Zero, 1970; screenplay by Aleksander Ścibor-Rylski), where soon after the evacuation of a small Mazurian town (Rosł巨̨k) by the German army in the spring of 1945 a demobilized army lieutenant Bartkowiak (Ryszard Filipski), now appointed the town's legal commissioner, has a mission to oversee the painful process of communitybuilding and establishing the communist rule. Rosłek, like a typical town from the Westerns, is an isolated community, lost amidst a seemingly boundless and unpopulated territory and thrown at the mercy of a ruthless gang formed by newly arrived drifters and rogues, terrorizing and exploiting the autochtonic population. Bartkowiak's integrity leads him to a confrontation with a gang led by Szczygieł which preys on the local population consisting of Mazurians: the part-Polish, part-German speaking Slavic population which, Bartkowiak believes, yet needs to discover its Polish roots and identity. In a long final gunfight scene Bartkowiak, helped by two accomplices, members of the wartime Communist youth organization (ZWM), succeeds in liberating the town from the bandits who are only pretending to represent the legitimate Polish authorities but in fact are bent on theft and plunder. The funeral of a native villager and one of the two ZWM heroes killed in the shootout, attended by the village community, symbolizes the emergence of the new socialist order, and of a "Polish" identity among the Mazurians. Meridian Zero conveyed a clear ideological message: the new socialist, Polish order represented by Bartkowiak, will bring about a promising future to the Mazurians and will reunite them with the Polish nation. Yet the 
costs of such a transformation are inevitably high and involve the role that has to be played by people like Bartkowiak, a very much Western-style embodiment of a lonely sheriff-a courageous agent of law and order, possessed of strong moral principles and manly courage that need to be mustered in order to effect a successful reunification of Poland with its Recovered Territories.

11 A number of Western-influenced movies made in the People's Republic of Poland were set on Poland's new eastern border, the Bieszczady mountains' natural beauty providing a locale-and a specific borderland social context-that inevitably invited comparisons with the Wild West. The earliest of them was Rancho Texas (1958, dir. Wadim Berestowski, screenplay by Józef Hen), telling the story of two students of zootechnics, Jacek and Marek, who come to Bieszczady to spend their summer vacation and earn some money working as "cowboys" (there is no precise Polish equivalent of the American original, as the word pastuch-shepherd-definitely lacks the kind of romantic and adventurous connotations raised by the word "cowboy"). The banal realities of a cow-puncher's life in the Bieszczady (rainy weather, ever-present mud, beans as the main wherewithal; and most painfully, boredom) are fortunately interrupted by a series of incidents, starting with a rodeo where Jacek wins for himself a good horse and continuing with his courtship of two attractive girls who appear on the scene. The plot includes Jacek and Marek's rivalry over Agnieszka, a research assistant to a geologist in search of precious mineral deposits; their discovery of an arms cache in an abandoned quarry; and the ensuing fight with the local gang of criminals. The film is self-consciously stylized as a "Western," featuring the picturesque landscapes, horse rides and chases, fistfights and gunplay. The "Rancho Texas" signboard mounted on the porch of the cowherds' shack is an openly tongue-incheek reference, just like the overall tone of the film where the imaginary world of Westerns is superimposed on the much less attractive, and banal, realities of everyday life in socialist Poland. Instead of the horse-mounted sheriff and his posse, the finale of the movie (following the Western-style shootout between Jacek and the gang leader) features the arrival of the militia in their military jeeps, establishing once and for all the rule of law and order in the borderland community. The movie was obviously meant to be, above everything else, entertainment for the Westerns-loving Polish public, but it was also sending a message: it mythicized the southeastern borderlands by using the clichés of the American West; in the process, the recent events which had taken place in those territories (the Second World War, the ethnic pogroms, the enforced communist takeover, the warfare between the local pro-Ukrainian fighters (UIA, Ukrainian Insurgent Army) and the Polish army and militia, were now being replaced in the cinemagoers' imaginaries by the tales of romance and adventure, where the intervention of the socialist state power to resolve the conflict and restore order could be seen as a "natural" and welcome occurrence.

The People's Republic's propaganda machine gladly sponsored works of fiction and film legitimizing the Polish Communist rule over the new borderlands, which provided an excellent occasion to glamorize the activity of the militia and border security forces as outposts of Polishness and the new socialist order. Within that framework, the sparsely populated, picturesque Bieszczady borderland, now the easternmost part of the country, ${ }^{7}$ was often cast as the part of Poland where the primitive living conditions and the tough challenges posed by the lingering presence of the anti-communist underground gave it the flavor of Poland's "Wild East." Łuny w Bieszczadach (Bieszczady in flames), Jan Gerhard's bestselling account of the Polish People's Army struggles with 
the UIA and the remnants of the Polish anticommunist resistance still operating in the Bieszczady after the war, was the best known example of using the literary medium to sanction and glamorize the activities of the Polish communist authorities in the Bieszczady region by constructing a narrative that can be read as a Polish Western, or "Eastern." The best known film version based on Gerhard's writing was Wilcze Echa (Wolves' Echoes, 1968, dir. Aleksander Ścibor-Rylski), a movie explicitly drawing on film Westerns' conventions and imagery. The film's plot takes place in 1948 in the Bieszczady, with a "lone ranger," the warrant officer Slotwina (Bruno O'Ya)-a veteran of wars with the local "bandits" and an ex-soldier discharged for disciplinary reasonsarriving in a little town to discover that his old friend Wladeczek who used to be commander of a local militia post, is missing and that the job has gone to a man named Moron. It turns out that Moron is the boss of a ring of corrupt militiamen whose goal, after disposing of Wladeczek, is to find the treasure once belonging to the UIA. In a series of fistfights and gunfights, Slotwina single-handedly dispatches all the bad guys and retrieves the lost treasure-not for himself, to be sure, but for the Polish authorities. The film had all the attractions of a Western: a fast-paced action, cavalry rides and pursuits across the spectacular landscapes of the Bieszczady mountains along with much gunplay, fistfights, a competition of tough and daring men (O'Ya, Perepeczko) for an attractive woman (Irena Karel), and the polarities of good and evil (Mieczyslaw Stoor playing the main bad character) one would expect from a Western. The mise-en-scène (Jan Grandys) and camera work (Stanislaw Loth) openly borrowed from the aesthetics of Westerns, including the "Western-style" look of the halfdeserted village with its wooden houses, the corral and the stockade at the border post, the high-angle panoramic vistas of wide open spaces, tracking shots of riders and horses in motion, low-angle takes of armed men, etc. All this was accompanied by the music of Wojciech Kilar, reminiscent of a number of film Western scores. The film was meant to provide entertainment, yet the image of Poland's southeastern borderland was certainly in tune with the contemporary propaganda portraying the Bieszczady as a lawless and almost empty terrain, waiting to be civilized by the legitimate communist rule represented by the Polish army and militia, shown as cooperating closely with the friendly Slovak and Soviet border troops. The truth, of course, was far more complex, as the region had recently seen its Ukrainian population evicted from their homes in a major ethnic cleansing operation (Akcja Wisła) staged by the Polish Communist authorities after the war, an event legitimized by the government-circulated myth that the Lemki, or local Ukrainian population, consisted of bloodthirsty nationalists. Another essential component of the immediately postwar context was the presence of the armed resistance by the Ukrainian Insurgent Army and Polish anti-communist underground which refused to lay down arms and continued fighting in the hope that the third world war would soon break out. The communist army and militia's role in that remote region was obviously to annihilate the armed underground, consistently portrayed by the government propaganda as ruthless bandits. While not dealing directly with the continuing borderland war and focusing instead on a classic crime story (treasure-seeking bandits terrorizing a village), the film undoubtedly served an ideological purpose of reinforcing the image of Poland's borderland as the all-butvacant "moving frontier" undergoing the inevitable civilizing process masterminded by the Polish Communist government. Interestingly, the film to some extent subverted this ideological message by showing some corrupt militiamen-which was generally a taboo in the People's Republic. It seems plausible to suspect that the film's reputation 
as a "Polish Western" made the censors turn a blind eye to this evident breach of the code.

While a number of other Polish action films located in the Recovered Territories during the postwar period could be viewed as "Polish Easterns" (e.g. Ogniomistrz Kalen [Artillery Sergeant Kalen], 1961, dir. Ewa and Czesław Petelscy), one should mention a relatively late movie, Wszyscy i nikt (All and None, 1977, dir. Konrad NałĘcki, screenplay by Janusz Przymanowski) as coming closer to a "Western" than most of them. The plot outline of Nałecki's film resembles that of the acclaimed Magnificent Seven (dir. John Sturges, 1960), serving as an ideologically charged morality tale about the exploits of six warreturning, demobilized Polish People's Army soldiers and one militiaman (to make up the required number) liberating an isolated mountain village from the "bandits," which in this particular case plainly meant the soldiers of the anti-communist underground. The final showdown ended in a victory of the peace-loving agents of the new social order, their leader-the indomitable communist Twardy (the Tough One, played by Emil Karewicz) performing the body count of the fallen baddies in the style of Yul Brynner in The Magnificent Seven. Similar to other socialist "Easterns," All and None stressed the masculine toughness and righteousness of the People's Army soldiers, contrasted with the duplicity and foolhardiness of the Home Army partisans inevitably meeting their inglorious death in the final shootout. Here again, like in the other "Easterns," the plot structure, the emphasized moral code (with stress on honor) and, most importantly, the manly heroism of the protagonists leading the village to "liberation" from the hands of anti-Communist guerillas-the use of tropes and narrative devices commonly perceived as characteristic of the Western genre work toward supplanting the myth of the Home Army with a new narrative, installing in the social imaginary a set of new, socialist, heroes. ${ }^{8}$

14 The intertextual and inter-generic quotations from the Western at the time of the People's Republic drew their strength from the great popularity of Western fiction and movies among the Polish public. In that regard, the Polish public was not at all unique among other European countries, West and East alike: the taste for Western fiction and movies was what both sides of the Iron Curtain had in common, for all the differences in the ideological and cultural context resulting in different readings and adaptations of the Western. Much has been written already about the spread of interest in the Wild West which was spurred by the success of not only fiction and films made in the U.S.A. and distributed in Europe, but also by the success of the European imitations of that production: one thinks, for example, of Westerns produced in Italy, West and East Germany or Yugoslavia. The cinematography of socialist Poland never produced its own imitation Westerns to speak of, ${ }^{9}$ even though, as I have argued, it found much use in utilizing the aesthetics and conventions of the classic Western to tell its own history within the larger narrative framework of the socialist propaganda. ${ }^{10}$ Also, the Polish film distribution, which allowed only a limited access to American movies (yet less limited and restrictive than in the other Soviet-controlled Eastern European countries), was more "generous" in releasing the Westerns than most other American film genres. As a result, the Polish public was quite well acquainted with many film Western classics, the iconic status of some Western films and film stars resonating with the Polish viewers to an extent unknown after 1989, when for a variety of reasons the Western lost some of its magic pull, not only in Poland, of course, but also in its homethe United States (one is tempted to think in this context of the Western as a genre whose popularity was strongly embedded in the culture of the Cold War). There can be 
no better proof of the persistent symbolic heft of the American Western in Poland than the famous Solidarity electoral campaign poster from June of 1989 featuring a frame from High Noon with Gary Cooper as Sheriff Will Kane, wearing a Solidarity pin above the silver star. The poster has since become a cult classic, having an independent life of its own: it has spawned a number of adaptations used for new and different political purposes. ${ }^{11}$

Despite the relative drop in popularity of Westerns vis-à-vis other genres in the postCold War world, some Polish artists kept their interest in the Western, which resulted in a few attempts to make "real" Westerns shot in the Polish scenery. It has to be stated outright, though, that those attempts-few as they were-can hardly qualify as successful. The most important part of this effort came from Józef Kłyk, author of a number of low-budget amateur productions which have never stood a chance of being commercially distributed and remain practically unknown. Kłyk's heroes all speak in the Silesian Polish dialect, as the films tell the story of Polish Silesian immigrants to the American West, mainly the settlers who founded the town of Panna Maria. ${ }^{12}$ One other example of an eccentric and abortive effort to make a Polish Western in recent years was Summer Love (Letnia miłość, 2006), directed and produced by Piotr Uklański. Despite starring some of the well-known Polish actors and a well-advertised half-minute stint by Val Kilmer, Uklański's Western-shot exclusively on Polish locations-turned out to be a complete flop and remains virtually unknown to the public.

At the same time a number of important Polish films made in recent years have been marked in the public reception as "Westerns," despite their makers' occasional protests. One of them was Wojciech Smarzowski's Róża (Rose, 2011), which picks up the postwar borderlands theme in a way which made some critics pronounce it a "Polish Western." Like in The Law and the Fist, the setting is in the Recovered Territories, the once German lands annexed by Poland in 1945. It tells the story of Tadeusz, an ex-Home Army soldier and participant in the 1944 Warsaw Uprising who is drawn to the northeastern borderland of Mazury (previously part of East Prussia) in an attempt to start a new life. Tadeusz is assigned quarters in the house of a German-speaking Mazurian woman (Rose) and eventually becomes her lover, protecting her and his new home from savagery at the hands of the Soviet soldiers and the Polish bandits who abound in the immediately postwar, frontierland situation. The film's grim, naturalistic mood accompanied by many acts of extremely graphic violence (which has become a mark of Smarzowski's filmmaking), if evoking the Western at all, belongs with the films of Peckinpah rather than classic Westerns. While the world presented in Rose is consistently dark, evil and corrupt, the film's focus on a single man's desperate fight for justice and survival inevitably perhaps brings to mind the moral symbolism of the Western, which didn't escape some critics' attention. The American critic Alissa Simon's review of Rose in Variety, for example, recognized this "Western" feel to Smarzowski's movie: "What in other hands might have played as costume melodrama focused on the victimized title character here takes the perspective of the loner hero, as Smarzowski gives the pic the hallmarks of a latter-day Western." A number of Polish critics likewise noted the Western-style quality of Smarzowski's film. The critic Tadeusz Sobolewski also referred to the film as a "Polish metaphysical Western," where a "universal, metaphysical battle between good and evil is taking place," and the protagonist "goes through a human-made hell, always keeping his cool, the way the Western heroes do." Sobolewski noticed that Rose engaged in dialogue with "another Polish Western," namely Jerzy Hoffman's The Law and the Fist, even the soundtrack 
(music by Michał Trzaska) raising associations with Komeda and Osiecka's famous Western-style ballad from Hoffman's movie. Sobolewski was quick to observe, though, that the ideological perspective present in The Law and the Fist (made in 1966) was no longer "achievable" in 2012, as "the viewer knows only too well that evil doesn't end with the defeat of Hitler." Yet, in the Polish critic's view the Western-style gore-andflesh scenes abounding in Rose are ultimately transcended by "pure and boundless love," giving Smarzowski's film a "metaphysical" dimension. ${ }^{13}$ It is worth noting that Smarzowski distanced himself from the idea that his film was meant to be a "latterday" Western. In an interview with Jakub Majmurek for Krytyka polityczna, cued by Marmurek that after the screening of Rose at the Gdynia Film Festival "everybody instantly thought of The Law and the Fist," Smarzowski came out with a protest against reading his film as "generic": "After I made Rose I read that I had made a Western. I never thought of that while shooting." Instead, he insisted that "the film's basic plot is about love-tough and built on ruins," and that he wanted to do a film about "love in inhuman times," with the tragic story of the Masurians, "a nation which fell victim to two nationalisms and whose destruction took place as if in passing" (Smarzowski).

Smarzowski's disclaimer did not prevent other critics from reading Rose as a Polish Western, especially when those readings stemmed from their authors' ideological commitments. A good case in point was that of Łukasz Adamski, a critic writing for the conservative online journal of opinion Fronda.pl. In Adamski's laudatory review, Rose was an "incredibly good" film on account of showing the "infernal, pure evil of Nazism and communism, the ethos of the Home Army and the meanness of the Bolsheviks." (What the Fronda.pl critic failed to observe, though, is that the moral heroism he admired in the portrayal of the Home Army protagonist was offset by the acts of savagery perpetrated on the Mazurians not only by the Soviets but also by the ethnic Poles). The critic expressed his disappointment that the film was passed over by the Gdynia film festival awards committee in favor of the "politically correct and antiAmerican" Essential Killing by Jerzy Skolimowski, and proclaimed Rose a "Polish Western" reminiscent of the films of Sam Peckinpah. "Watching Smarzowski's movie," he wrote, "I had the feeling I was visiting the Wild West," even though, as he argued, Peckinpah's films with their staged "ballet of death" did not achieve the level of cruelty present in Smarzowski's realistic portrayal of the violence that had actually taken place in the Recovered Territories. Significantly, in Adamski's view the slaughter of the Masurians could be compared to the "massacres perpetrated on the American settlers, or even to the butchery of the Native Americans" (Adamski).

Adamski's attempt to combine his taste for Westerns with a pro-American attitude, coupled with his belief in the righteousness of the Poles as contrasted with the "mean Bolsheviks" and "evil Germans" seems representative of the paradigmatic knot of beliefs embraced by the adherents to Poland's own exceptionalist narrative, usually paralleled by displays of pro-American sentiment. One can trace this attitude in the voice of the Polish conservative intellectual Ryszard Legutko, declaring his fondness for the classic Western with its clear-cut moral philosophy. In one of his essays, Legutko praised the ethics of High Noon and bemoaned the moral decline he traced in the "new" Westerns of Sam Peckinpah and Arthur Penn. ${ }^{14}$ The New Western's "historicism," in Legutko's view, undermined the universal and timeless appeal of American myth, along with the myth of American uniqueness, and was opening the door to new leftist ideologies and intellectual "fads." All this led the Polish critic to the defense of 
American culture against the "European" notions of high culture: "the case of the Western demonstrates... a deadly effect of high culture on mass culture" (Legutko 208).

The moral certainties of the classic Western occasionally elicited a nostalgic response on the opposite end of the ideological/political spectrum, as reflected in the context of Waldemar Pasikowski's 2012 Aftermath (Pokłosie). Like Rose, Aftermath was not a Western sensu stricto, though it can be said to contain elements reminiscent of a Western. It takes place in a small, shabby-looking provincial town in Eastern Poland, whose population mostly consists of ignorant and brutish anti-Semites. It is a story of Franciszek Kalina (Ireneusz Czop), a Polish immigrant to the United States, who returns home to his village and joins his younger brother Józef (Maciej Stuhr) in an attempt to uncover the dark secrets surrounding the death of the local Jewish population at the hands of their Polish neighbors during the Second World War-the Polish viewers of the film could easily make the connection between the events narrated in the film and the real-life pogrom of the Jews which occurred in July 1941 in Jedwabne. Józef and Franciszek stand up to the whole village community who act in a conspiracy to cover up the shameful facts from the past, and even though they succeed in their fight to uncover the truth, Józef pays the ultimate price for his righteousness, as he is killed and crucified by the anonymous members of the community. While not exactly a "Western" story, the film nonetheless invited comparisons with some American classics. J. Hoberman, for example, in his perceptive New York Times review saw it as "a Polish thriller (which) has affinities with American 'guilty town' Westerns like Bad Day at Black Rock and High Plains Drifter" (Hoberman). Predictably, the film stirred up a big public debate in which both its harsh critics (representing the nationalist viewpoint, denying the Polish complicity in the Holocaust) and the "liberals," or the Polish cultural left, looked for affinities with American Westerns. One Polish critic of the movie, for example, described it as a Western about Polish anti-Semites, in an obvious attempt to disavow the movie. On the opposite end of the ideological/political spectrum, actor Daniel Olbrychski compared Aftermath to High Noon: "High Noon is one big accusation of a community permeated with evil-in Hadleyville, like in Aftermath, only one righteous person has the courage to stand up to the bandits. That film should have led to assaults and spitting on Gary Cooper, but instead it is an American film classic." Olbrychski believed the hero played by Maciej Stuhr to be the equivalent of Gary Cooper's role in High Noon, and put Aftermath "in the category of historical revisionism, along with numerous American films critical of the slaughter of the Indians, the Vietnam War and racism" (Olbrychski). Significantly, Waldemar Pasikowski, the film's director, and Maciej Stuhr, who played the main role-both of whom were viciously attacked by their "patriotic" opponents-attempted to deflect the attacks by calling their film a Western. In an interview for Do Rzeczy magazine, Stuhr declared that "Pasikowski himself admits that Aftermath is a Western. There are no Germans, no Jews in it. Everybody sees the film lacks in nuance. But I don't agree that this lowers its significance.... It's a very much black-and-white movie, not presenting all perspectives perhaps, but it's an honest movie" ("Maciej Stuhr przeprasza").

This review of Polish films mostly playing with, but not actually imitating, the Western formula or trying to be like "real" Westerns (if only in the way the East German/ Yugoslav productions once aspired to) should not omit Piotr Mularuk's Yuma (2012). Apart from all the Western tropes traceable in the movie, it provides a post-socialist, or perhaps also post-modern counterpoint to The Law and the Fist, visibly engaging in dialogue with the latter. Yuma's protagonist, the young Zyga (Jakub Gierszał) who 
makes a living smuggling and stealing goods from the neighboring town across the Polish-German border, is clearly no Kenig, contemptuous of materialism and personal gain. Zyga, who is initiated into a life of crime by his aunt-a brothel keeper (Katarzyna Figura)-ends up leading a gang of young criminals, the mock-heroes of the new Polish capitalism where the accumulation of wealth begins with theft and bootlegging. Like Siwowo/Graustadt from The Law and the Fist, Yuma is set near the Polish-German border, in Lower Silesia, and both films grapple with the problem of crime. Yet, while the protagonist in The Law and the Fist takes on the bad guys (szabrownicy) who are stealing what has become public property, Zyga and his gang-the main characters in Mularuk's film-engage in shady dealings not less repugnant than those of their criminal counterparts from Hoffman and Skórzewski's movie. What makes the practice less odious, in terms of the film plot, is that Zyga shares the loot with his friends, and the drinking orgies taking place at the local bar (named "Eldorado") to celebrate the trans-border transactions bring to mind some unruly scenes from the U.S.-Mexican borderland to be found in films like The Wild Bunch. Zyga's "wild bunch" crimes clearly do not carry the same moral weight as the szaber in The Law and the Fist, in fact they are often represented as mock-heroic exploits rather than dark crimes eliciting moral outrage.

21 The film abounds in Western cues, starting with the title, of course, which sends the viewer to the classic American Western (Delmer Daves, 3:10 to Yuma, 1957), but is in fact mainly a reference to the Polish slang terms for stealing (jumanie, jumać)-a noun and a verb adopted from Daves's movie in reference to the cross-border theft and the bootlegging business thriving on the Polish-German border in the early 1990s, after the border was opened for visa-free crossing. Why Yuma? Apparently because the train from Zielona Góra to Berlin, a convenient means of transportation to bootleggers, used to set out precisely at 3:10. Needless to say, the playful choice of the title made Mularuk's film an ironic commentary on-to use another trope from the Westernshow the West was now being won, with the moral code of the classic Western (and of the "socialist morality") brushed aside by the new rules of the rough-and-ready "frontier" capitalism. In keeping with its title, Mularuk's film is filled with Western tropes, though used mainly as pastiche: Zyga, an aficionado of Western-style Americana and American kitsch, wears a stolen leather vest and a pair of cowboy boots bought for the money earned in the bootlegging business, and we see him lugging a lifesize cowboy dummy into a cinema showing, of course, Delmer Daves's 3:10 to Yuma. Yet, for all his use of the Western fetishes and props Zyga is hardly a tough hero: beneath the cowboy costume-the leather vest and boots-we can spot a "softie": a young man who is more of a romantic dreamer than a profit-oriented bandit. And even though Zyga is going to meet his punishment (at the hands of the Russian mafia) near the end of the movie, one gets the feeling the makers of the film could not resist perceiving the "wild bunch" of thieves and bootleggers as the avant garde of Polish capitalism. Sleazy characters as they are, they are also possessed of some redeeming traits, the "entrepreneurial spirit" not the least among them. The thieves-as-cowboys motif seems to lead to the construction of a new myth of origins of the new capitalist order emerging from the borderland's "grey zone" of the early 1990s, with the "border" not only synonymous with the Polish-German frontier, but in a figurative sense marking the divide between East and West, between "raw" and developed capitalism.

The movies I have discussed here show an uncanny ability of the American Western - "tested" over a long time in a rapidly changing context of a distant country-to lend 
itself to many different adaptations, borrowings and interpretations. To be sure, the Western has amply shown its "genre bender" malleability and openness to other genres in the U.S. movie production itself: one thinks for example of the generic crossbreeding evident in the case of Western and science-fiction movies and war movies, or such Hollywood "Easterns" as Spielberg's Raiders of the Lost Ark (Eisele). Yet its international, or transnational, career has been equally spectacular, by which I mean much more than the success of the "spaghetti" western and other attempts of making "American" movies abroad, or in co-production with Hollywood-contribute, as they certainly did, to the development of the genre. Some European directors will certainly be tempted to follow the example of Sergio Leone and produce "real" Westerns-the most recent example is that of Jacques Audiard, who in his own words "had never even previously thought about doing a western," but has recently finished The Sisters Brothers (2018), a French-American co-production shot in Southern Spain but set in the time of the California Gold Rush with a \$40-million budget allowing for many special effects and the hiring of American stars like Jake Gyllenhaal and Joaquin Phoenix (Williams). In the estimate of Manohla Dargis, in his film Audiard plays with the film Western genre, but despite the things that would be unacceptable in a John Wayne movie, like "the amusingly deployed coarse language, the shots to the head and sprays of blood... (he) isn't attempting to rewrite genre... which is one of the movie's virtues" (Dargis).

But, as it has been argued here, one can "do a Western," play with the Western tropes, without making an actual Western movie-which was the way most Polish filmmakers have utilized the genre. A number of non-American film productions have done something similar, just to mention the "sukiyaki" and "kimchi," or "de-Westernized (East Asian) Westerns" analyzed recently by Vivian P. Y. Lee (Lee). In Europe, a recent German film by Valeska Grisebach seems to be a good case of a transnational and hybridized use of the cultural material offered by the film Western. Grisebach's movie with a misleading generic title Western (2017) is anything but a genre film, and in most ways is not a Western at all, as it deals with a German construction team working on a remote site in the Bulgarian-Greek borderland and their cross-cultural encounters with the local population. As Grisebach admits, the East European borderland setting she selected for her film seemed particularly fit for telling her story:

I started off by travelling between Bulgaria and Romania because the story drew me to Eastern Europe and also because of all the legends that sprung up there following the end of communism: the idea of the 'Wild East' or the feeling that that was some sort of vacuum or empty page at the time, even if things are already very different there now. And once I was in Bulgaria, I was drawn to the border region because so much cultural mixing has taken place there, between Bulgarians and Greeks, Turks, and Serbs.

The prominent place of borderlands in the imaginary and the cultural memory of Central and Eastern Europeans seems to be a factor facilitating the domestication of the Western and accounting, if only in part, for its popularity. To conclude this article dealing with the Polish attempts to domesticate and utilize the Western, I would like to quote another fragment from James Latimer's interview with Grisebach where she explains why she called her film a "Western," as she seems to speak not only for herself, but for the other European artists for whom the Western remains a meaningful point of reference and a vital source of inspiration for telling their own stories:

When I start thinking about a film, I do so independently of a story. The starting point is a theme, and then I like to devote my time to researching that theme in a very personal way; it's only afterwards that I start writing a narrative. And the 
Western genre was indeed the starting point, because I realized just how fascinated I'd been by it, ever since my childhood. It was as if I felt homesick for the Western and therefore wanted to wander back into it in my own way via film. I grew up with Westerns and the heroes of the genre, although looking back I realize that watching those films as a child-and a girl in particular-is different.... But for me, it was just exciting to engage with the Western or even dance with it, as it were, to return to all those solitary heroes, to their loneliness, to the themes they carry with them, all those heavy burdens.... And so giving the film the title Western started off as kind of a reminder of all those things, and that's where I set off from. And in talking to other people about it, it became clear that despite it being an American genre, it's a genre we all carry within us: everyone has images of the Western in them. (Latimer)

"Dancing" with the Western... by choosing this metaphor (sending us to the title of Kevin Kostner's 1990 movie), Valeska Grisbach not only described her own way with the Western, but seems to have found the right expression for the work of the Polish filmmakers inspired by the American genre.

\section{BIBLIOGRAPHY}

Adamski, Łukasz. “Róża Smarzowskiego: ten film jest jak granat rozwalajĄcy serce.” Fronda.pl., Feb. 5, 2012. http://www.fronda.pl/a/quotrozaquot-smarzowskiego-ten-film-jest-jak-granatrozwalajacy-serce,17667.html. Accessed October 14, 2018.

Bobowski, Sławomir. "Wielka mistyfikacja. Ziemie Odzyskane w kinematografii PRL-u." PamiEcć $i$ przyszłość 1.1 (2008): 41-49. Print.

Campbell, Neil. Post-Westerns. Cinema, Region, West. Lincoln: University of Nebraska Press, 2013. Print.

Corkin, Stanley. Cowboys as Cold Warriors. The Western and U.S. History. Philadelphia: Temple University Press, 2003. Print.

Dargis, Manohla. "Review: Blood Is Never Simple in 'The Sisters Brothers." The New York Times Online, Sept. 20, 2018.

Eisele, John C. "The Wild East: Deconstructing the Language of Genre in the Hollywood Eastern." Cinema Journal 41/4 (2002): 68-94. https://www.jstor.org/stable/1225789.

Hoberman, J. “The Past Can Hold a Horrible Power." The New York Times Online. Oct. 25, 2013.

Latimer, James. “At the Frontier: Valeska Grisebach on Western.” Cinema Scope Online. http:// cinema-scope.com/spotlight/at-the-frontier-valeska-grisebach-on-western/. Accessed October 5, 2018.

Lee, Vivian P. Y. “Staging the 'Wild Wild East': Decoding the Western in East Asian Films." The Post-2000 Film Western. Contexts, Transnationality, Hybridity. Ed. Marek Paryz and John Leo. London: Palgrave, Macmillan, 2015. 147-166. Print.

Legutko, Ryszard. Etyka absolutna i społeczeństwo otwarte. Kraków: Arcana, 1997. Print.

Letnia miłość (Summer Love). Directed by Piotr Uklański, 2006. 
Łoziński, Łukasz. „Okres pionierski na 'Ziemiach Odzyskanych' w filmie fabularnym PRL. Obraz społeczeństwa.” PoczĄtek. Ed. Marta Błaszkowska et al. Kraków: Inicjatywa Humanistyczna Babel 2015. 9-38. Print.

"Maciej Stuhr przeprasza za Cedynį̨ i broni Pokłosia." wPolityce.pl. Nov. 26, 2012. https:// wpolityce.pl/kultura/246770-maciej-stuhr-przeprasza-za-cedynie-i-broni-poklosia-chocprzyznaje-to-jednostronny-film. Accessed October 14, 2018.

Olbrychski, Daniel. „Bohater ‘Pokłosia’ jak Gary Cooper.” wPolityce.pl. Nov. 29, 2012. https:// wpolityce.pl/kultura/246793-olbrychski-bohater-poklosia-jak-gary-cooper. Accessed October 14, 2018.

Paryz, Marek, and John Leo, eds. The Post-2000 Film Western. Contexts, Transnationality, Hybridity. London: Palgrave, Macmillan, 2015. Print.

Pokłosie (The Aftermath). Directed by Waldemar Pasikowski, 2012.

Południk zero (Meridian Zero). Directed by Waldemar Podgórski, 1970.

Prawo i pięść (The Law and the Fist). Directed by Jerzy Hoffman and Edward Skórzewski, 1964.

Rancho Texas. Directed by Wadim Berezowski, 1958.

Róża (Rose). Directed by Wojciech Smarzowski, 2012.

Simon, Alissa. "Review: Rose." Variety. June 16, 2011. https://variety.com/2011/film/marketsfestivals/rose-1117945460/. Accessed October 14, 2018.

ŚlĄski szeryf (Silesian Sheriff). Directed by Józef Kłyk, 2014.

Smarzowski, Wojciech. “Moje filmy majĄ prowokować.” Krytyka polityczna pl., Oct. 19, 2011. www.krytykapolityczna.pl/Serwiskulturalny/SmarzowskiMojefilmymajaprowokowac/ menuid431.html. Accessed March 17, 2016.

Sobolewski, Tadeusz. “Polski Western metafizyczny.” Wyborcza.pl, June 10, 2011. http:// wyborcza.pl/1,75410,9757956,Polski_western_metafizyczny.html. Accessed Oct. 14, 2018.

Sowa, Jan. Fantomowe ciało króla. Peryferyjne zmagania z nowoczesnĄ formĄ. Cracow: Universitas, 2011. Print.

Western. Directed by Valeska Grisebach. 2017.

Wilcze echa (Wolves' Echoes). Directed by Aleksander Ścibor-Rylski, 1968.

Williams, Thomas Chatterton. “Can't ‘the French Scorsese' Pull off a Western?” The New York Times Magazine Online, Oct. 12, 2018.

Woroszylski, Wiktor. "Polski western.” Film 41 (1963): 5. Print.

Wszyscy i nikt (All and None). Directed by Konrad NałĘcki, 1977.

Yuma. Directed by Piotr Mularuk, 2012.

Zwierzchowski, Piotr. Polskie wczoraj i dziś. Kino nowej pamiĘci. Obraz II wojny światowej w kinie polskim lat 60. Bydgoszcz: Wyd. Uniwersytetu Kazimierza Wielkiego, 2013. Print. 


\section{NOTES}

1. For an excellent source on Poland's self-perception vis-à-vis the West and the mythic "East" (complicated by Poland's repressed post-colonial mindset, mixed with Polish messianism and a denial of "unwanted" history), see Jan Sowa's Fantomowe ciało króla, especially 443-536.

2. After 1989, the ideologically charged term Ziemie Odzyskane (Recovered Territories) largely dropped out of use and was replaced by the "neutral" phrase Northern and Western Territories).

3. See Łoziński, “Okres pionierski na „Ziemiach Odzyskanych” w filmie fabularnym PRL. Obraz społeczeństwa," and Bobowski, "Wielka mistyfikacja. Ziemie Odzyskane w kinematografii PRL-u." 4. I will use the word "militia" for the Polish milicja realizing it is, to some extent, a translator's false friend: the People's Republic replaced the word policja (police)-used before the Second World War-by milicja (militia) as a political gesture signifying the new socialist origins of the force contrasted with its "capitalist" equivalent, policja. Which, of course, was a semantic ploy to legitimize the communist state law enforcement apparatus. Usually, of course, the word "militia" refers to a military force made up of non-professional soldiers, or is linked to rebel or terrorist activities.

5. Szaber is a word borrowed from the Yiddish, and in this context functions as a noun denoting stolen property which used to belong to a now-absent owner.

6. In fact, the "rise of the new socialist order" theme deconstructs itself in the movie, since among the szabrowniki are also some corrupt representatives of the new regime.

7. The Bieszczady, while not being part of the once German-owned Recovered Territories (that region belonged to Poland before WWII), was often represented in the Polish propaganda as a region that was actually recovered from Ukrainian nationalists, including the Łemki, who were removed by force to Northwestern Poland (operation Akcja Wisła) and Ukrainian nationalists (UIA), eliminated by the Polish Communist forces with Soviet help.

8. The clearly political use of the film Western clichés to tell the official narrative of the founding of the People's Republic reflects-in due proportions-the political and ideological function played by Westerns in Cold-War America: see Corkin, Cowboys as Cold Warriors. The Western and U.S. History. What is meant by "due proportions" here is the fact that the film Western tropes, intriguing as they are, have to be seen as just a part of the massive propaganda effort to legitimate and glamorize the Communist takeover through the medium of film sponsored by Poland's culture industry, with as many as $\mathbf{3 0 0}$ war films (both feature films and documentaries) made between 1960-1970 comprising what Piotr Zwierzchowski calls "the cinema of new memory."

9. This lack was qualified by a few exceptions, i.e. several film shorts being adaptations of nineteenth century prose. Among them were two films directed by Jerzy Zarzycki in 1967, A Comedy of Errors, a film short based on a story by Henryk Sienkiewicz set in nineteenth century California and The Man Who Corrupted Hadleyburg, an adaptation of Mark Twain's story. One should also mention The Matter of Conscience (1969), dir. Ewa and Czesław Petelscy, based on Ambrose Bierce's Civil War story, "An Incident at Owl Creek."

10. The lack of Polish-made imitation Westerns was more than compensated by a long list of popular Western fiction writers, including such names as Nora Szczepańska, Wiesław Wernic, and Sat-Okh (Stanisław Supłowicz).

11. For example, in the referendum deciding about Poland's entry into the European Union (2003) the famous photo of Gary Cooper was once more re-edited, with the insignia of the EU replacing the Solidarity pin. Likewise, in a 2009 poster protesting further tightening of antiabortion laws, the Gary Cooper silhouette from the Solidarity poster was replaced by that of a woman. It is not certain, though, how long the sign will retain its symbolic power: young people in Poland today can no longer be "safely" expected to have a recognition of High Noon or Gary Cooper, which I've become painfully aware of in some of my American culture classes. 
12. Kłyk's productivity in turning out one "Silesian" Western after another is truly amazing, with his first attempt dating back to 1970, and the most recent one (The Silesian Sheriff) made in 2014. His amateur films have since acquired a cult following, mostly in Silesia, and he has been the hero of a number of documentary movies.

13. Smarzowski's other films, like The Dark House (Dom zły, 2009), or most recently Clergy (Kler, 2018), can perhaps be adequately described as "anatomies of evil."

14. Legutko's reading of the Western genre misses the double-coding present in films like High Noon, raising questions with regard to the moral certainties of Cold War America he seems to embrace with a misplaced nostalgia characteristic of Poland's right-wing ideologues and their followers.

\section{ABSTRACTS}

This article deals with the influence of American Westerns on the work of the Polish film directors who chose to adapt the language of the film Western to construct their narrations about Poland's postwar borderlands, including the so-called Recovered Territories and the Bieszczady region. The analysis of selected films draws on the ideological and cultural context of film- and myth-making in Poland, and points to the larger patterns of domesticating the American mass culture repertoire in Europe.

\section{INDEX}

Keywords: Western films, borderlands, cultural adaptations, Polish film, Recovered Territories, Bieszczady, Silesia

\section{AUTHOR}

\section{PIOTR SKUROWSKI}

Piotr Skurowski is Associate Professor and current Chair of the Department of English at the SWPS University of Social Sciences and Humanities, Warsaw. His main interests lie in the areas of U.S. Cultural History and Cultural Studies. His publications include monographs on Henry Adams and on the image of Europe in American Progressivism, as well as a number of articles and edited volumes on U.S. history and culture. 